\title{
СТАН ТА ПЕРСПЕКТИВИ РОЗВИТКУ СТРАХОВОГО РИНКУ УКРАЇНИ
}

Онісіфорова В.Ю., канд. екон. наук, доцент

Шершенюк О.М., канд. екон. наук, доцент

\section{Харківський національний автомобільно-дорожній університет}

Постановка проблеми. Сучасний стан ринку страхових послуг відкриває можливість розширення діяльності страхових компаній в напрямку все більшої кількості видів не лише обов' язкового, але й добровільного страхування. Однак особливості вітчизняного страхового ринку, економічного розвитку держави та законодавства визначають певні обмеження для розширення діяльності страхових компаній в деяких напрямках. Отже, на сьогодні перед страховими компаніями постає проблема обрання перспективних напрямків розвитку 3 урахуванням таких головних критеріїв, як темпи зростання страхових премій на сегменті, темпи росту страхових виплат та динаміка збитковості за видами страхування.

Аналіз останніх досліджень та публікацій. Проблемам страхування присвятила свої дослідження велика кількість авторів, а саме Базилевич В.Д., Базилевич К.С., Пікус Р.В., Приказюк Н.В., Моташко Т.П., Любашенко І., Ротова Т., Фисун В. І., Ярова Г. М., Прилипко С. М., Ярошенко О. М., Занфірова Т. А., Аркатов Я. А., Білик О. І., Качмарчик С. А. [1-8] та багато інших. Але на сьогодні найбільш значна частина досліджень присвячена проблемам впровадження медичної реформи та особливостям реагування на неї страхового ринку, а також дослідженню особливостей страхування відповідальності власників наземних транспортних засобів.

Невирішені складові загальної проблеми. Не зважаючи на значну кількість досліджень потребує подальшого розгляду проблема визначення перспективних напрямків розвитку страхового ринку України і визначення оптимальної структури діяльності страхових компаній за видами страхування. 
Формулювання цілей статті. Метою статті є визначення найбільш перспективних видів страхування для страхових компаній України за темпами росту показників страхових премій, страхових виплат та динаміки збитковості.

Виклад основного матеріалу дослідження. На сьогодні страховий ринок України досить динамічно розвивається, але головною проблемою для подальшого розвитку страхових компаній стає велика насиченість ринку традиційних видів страхування. Отже, необхідним $є$ пошук нових джерел надходження страхових премій, а також створення нових страхових продуктів. Крім цього, слід визначитися 3 ефективністю існуючих видів страхування в портфелі вітчизняної страхової компанії.

Проаналізуємо структуру страхового ринку України за даними 2017 року та прогнозними даними на 2018 рік на прикладі страхових компаній, які займають лідируючі позиції на ринку кожного з видів страхування в Україні.

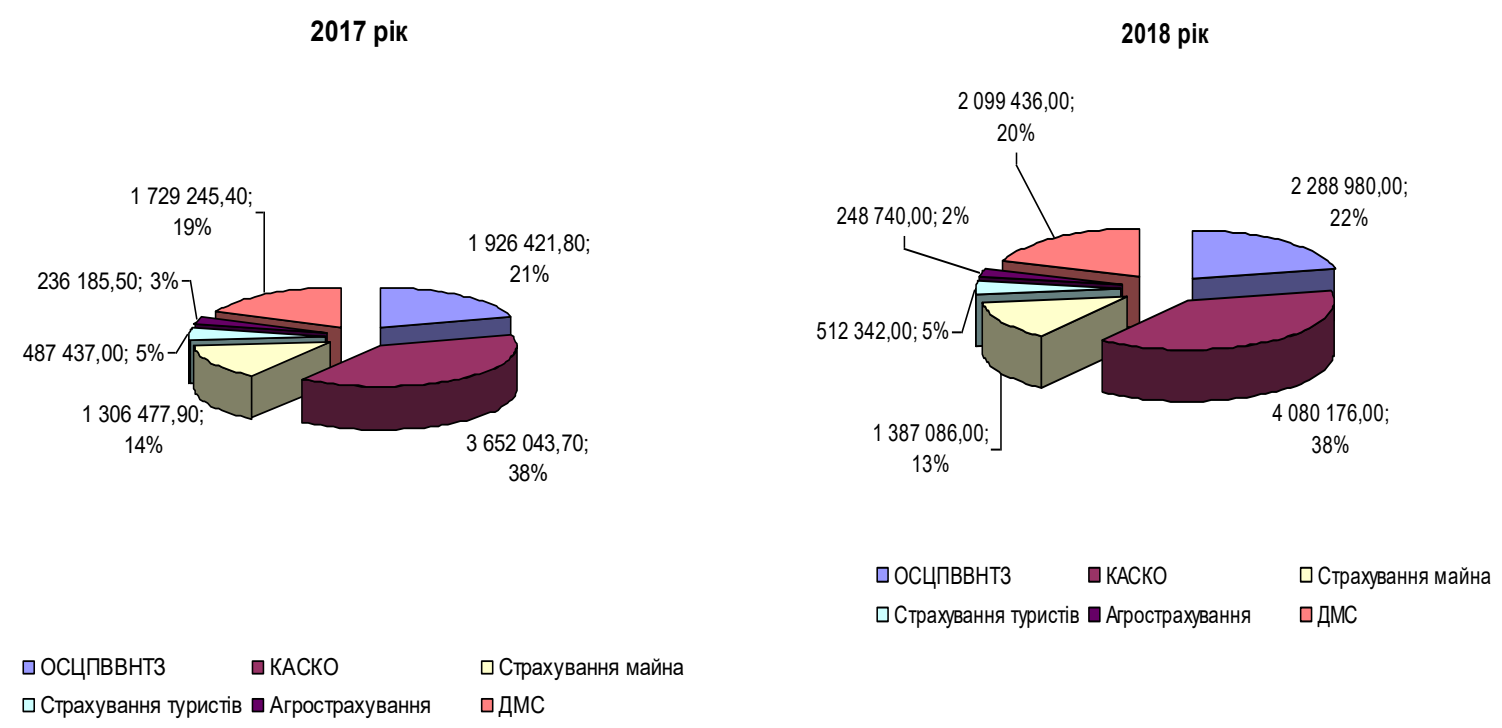

Складено авторами на основі [9]

Рис. 1. Структура страхового ринку України за обсягами страхових премій, тис. грн.

Як видно з рис. 1, портфель страхових продуктів за структурою останніми роками $є$ доволі стабільним, без значних коливань та відхилень, однак у вартісному вираженні є тенденція до збільшення розмірів отриманих страхових 
премій. Головними джерелами надходження коштів для страхових компаній України є:

- страхування транспортних засобів від певних видів збитків (так зване, $\mathrm{KACKO}$;

- обов'язкове страхування цивільно-правової відповідальності власників наземних транспортних засобів (так звана, автоцивілка);

- добровільне медичне страхування (ДМС);

- страхування майна; страхування туристів (головним чином, медичне страхування);

- агрострахування.

Розглянемо динаміку розвитку страхового ринку України за 20152018 роки з точки зору приросту страхових премій за кожним з названих видів страхування. В табл. 1 наведена інформація про обсяги зібраних страхових премій на страховому ринку основними компаніями, які спеціалізуються на даних видах страхування.

Таблицуя 1

Динаміка розвитку страхового ринку за рівнем страхових премій у 2015-2018 роках, тис. грн.

\begin{tabular}{|c|c|c|c|c|}
\hline Показник & 2015 рік & 2016 рік & 2017 рік & $\begin{array}{l}2018 \text { рік } \\
\text { (прогноз } \\
\text { авторів) }\end{array}$ \\
\hline 1 & 2 & 3 & 4 & 5 \\
\hline \multicolumn{5}{|c|}{ КАСКО } \\
\hline Загалом & 2559925,10 & 3095673,00 & 3652043,70 & 4080176,00 \\
\hline Порівняно з 2015 роком & & 1,21 & 1,43 & 1,59 \\
\hline До попереднього року & & 1,21 & 1,18 & 1,12 \\
\hline \multicolumn{5}{|c|}{ ОСЦПВВНТЗ } \\
\hline Загалом & 1484506,60 & 1718933,00 & 1926421,80 & 2288980,00 \\
\hline Порівняно з 2015 роком & & 1,16 & 1,30 & 1,54 \\
\hline До попереднього року & & 1,16 & 1,12 & 1,19 \\
\hline \multicolumn{5}{|c|}{ ДМС } \\
\hline Загалом & 1150141,20 & 1479299,00 & 1729245,40 & 2099436,00 \\
\hline Порівняно з 2015 роком & & 1,29 & 1,50 & 1,83 \\
\hline До попереднього року & & 1,29 & 1,17 & 1,21 \\
\hline \multicolumn{5}{|c|}{ Страхування майна } \\
\hline Загалом & 846135,90 & 1096309,00 & 1306477,90 & 1387086,00 \\
\hline
\end{tabular}


Продовження таблииі 1

\begin{tabular}{|c|c|c|c|c|}
\hline 1 & 2 & 3 & 4 & 5 \\
\hline Порівняно з 2015 роком & & 1,30 & 1,54 & 1,64 \\
\hline До попереднього року & & 1,30 & 1,19 & 1,06 \\
\hline \multicolumn{5}{|c|}{ Страхування туристів } \\
\hline Загалом & 260668,10 & 392684,00 & 487437,00 & 512342,00 \\
\hline Порівняно з 2015 роком & & 1,51 & 1,87 & 1,97 \\
\hline До попереднього року & & 1,51 & 1,24 & 1,05 \\
\hline \multicolumn{5}{|c|}{ Агрострахування } \\
\hline Загалом & 79210,10 & 159940,00 & 236185,50 & 248740,00 \\
\hline Порівняно з 2015 роком & & 2,02 & 2,98 & 3,14 \\
\hline До попереднього року & & 2,02 & 1,48 & 1,05 \\
\hline
\end{tabular}

Складено авторами на основі [9]

Як бачимо, ринок КАСКО має тенденцію до зростання, але темпи такого зростання останнім часом зменшуються. Фактично зростання значною мірою пояснюється збільшенням розміру вартості полісу страхування за рахунок приросту вартості транспортних засобів внаслідок коливання валютного курсу гривні. Крім того, на ринку КАСКО вже визначилися страхові компанії-лідери, а ринок $є$ статичним та розподіленим, тобто перспективи виходу на цей ринок для інших страхових компаній обмежені. Однак, за поглядом деяких експертів у 2019 році очікується зростання ринку КАСКО, як наслідок врегулювання проблеми з оформленням вживаних автомобілів з Європи, в результаті якого очікується зростання попиту на вживані автомобілі всередині України та пожвавлення ринку нових автомобілів.

Проаналізуємо ринок обов'язкового страхування цивільно-правової відповідальності власників наземних транспортних засобів. Як бачимо, ринок страхування цивільно-правової відповідальності власників наземних транспортних засобів є більш стабільним і має стабільні темпи до зростання. До того ж, це обов'язковий вид страхування, тобто попит на таку страхову послугу зформується у будь-якому разі і в майбутніх періодах. Однак, негативною тенденцією для страхових компаній на ринку цього виду страхування $\epsilon$ обмеженість у вартості полісу, яка в умовах нестабільного валютного курсу 
гривні може призвести до підвищення рівня збитковості цього виду страхування для компанії.

Перспективним в сучасних умовах для страхових компаній України стає такий вид добровільного страхування, як добровільне медичне страхування. Як бачимо, цей вид страхування має більші, порівняно з першими двома видами, темпи зростання обсягів страхових премій. Головним аспектом, який визначає попит на цей вид страхування є проведення медичної реформи в Україні, відповідно до якої, більша кількість медичних закладів отримує можливість вести співпрацю зі страховими компаніями. Підвищується інтерес і з боку потенційних клієнтів, які мають бажання отримувати більш якісні медичні послуги, зокрема до таких клієнтів відносяться і роботодавці, які бажають здійснювати корпоративне медичне страхування.

Дуже нестабільним за рівнем страхових премій протягом досліджуваного періоду виявився такий вид страхування, як добровільне страхування майна. Не зважаючи на те, що цей вид страхування традиційно є найменш збитковим для компаній, темпи росту страхових премій 2018 року прогнозуються найменшими. Негативно на цих показниках має сказатися і введення на частині території України воєнного стану, що додатково скоротить кількість укладених договорів страхування майна.

Нестабільною є і ситуація на ринку страхування туристів. У 2015 2017 роках за цим видом страхування спостерігалися високі темпи зростання обсягів страхових премій, зокрема за рахунок збільшення обсягів зовнішнього туризму, але на сьогодні досягнута певна насиченість туристичного ринку, а відповідно і ринку туристичного страхування.

Надзвичайно цікавим в сучасних умовах $є$ ринок агрострахування. Протягом 2015-2017 років цей ринок дуже динамічно розвивався. Але цей вид страхування $\epsilon$ найменш прогнозованим серед усіх інших видів, бо рівень збитковості і рівень попиту на страхові послуги значною мірою визначаються погодними умовами. При цьому несприятливі погодні умови сприяють збільшенню попиту на страхування з боку підприємств аграрного сектору, але 
для страхових компаній вони є важелем, який підштовхує до скорочення діяльності. Такі тенденції цілком пояснюють значне зниження темпів зростання обсягів страхових премій у 2018 році, який став надзвичайно ризикованим 3 точки погодних умов і їх впливу на ризики у сільському господарстві.

Однак перспективність певного виду страхування для страхових компаній визначається не лише за обсягами премій, але й за рівнем збитковості, тобто питомою вагою страхових виплат у розмірі страхових премій. Проаналізуємо динаміку рівня збитковості окремих видів страхування ( табл. 2).

Таблиця 2

Динаміка рівня збитковості основних видів страхування у 2015-2018 роках, \%

\begin{tabular}{|c|c|c|c|c|c|c|c|}
\hline Вид страхування & 2015 & 2016 & 2017 & 2018 & $\begin{array}{c}2016 \text { p. до } \\
2015 \text { p. }\end{array}$ & $\begin{array}{c}2017 \text { р. до } \\
2016 \text { p. }\end{array}$ & $\begin{array}{c}2018 \text { р. до } \\
2017 \text { p. }\end{array}$ \\
\hline ОСЦПВВНТЗ & 36,42 & 40,3 & 51,08 & 48,01 & 1,11 & 1,27 & 0,94 \\
\hline КАСКО & 48,32 & 46,9 & 50,12 & 53,71 & 0,97 & 1,07 & 1,07 \\
\hline Страхування майна & 20,32 & 5,1 & 9,25 & 19,89 & 0,25 & 1,81 & 2,15 \\
\hline $\begin{array}{c}\text { Страхування } \\
\text { туристів }\end{array}$ & 36,09 & 31,1 & 31,16 & 31,97 & 0,86 & 1,00 & 1,03 \\
\hline Агрострахування & 8,35 & 7,4 & 36,19 & 11,27 & 0,89 & 4,89 & 0,31 \\
\hline ДМС & 63,27 & 57,9 & 59,33 & 61,21 & 0,92 & 1,02 & 1,03 \\
\hline
\end{tabular}

Складено авторами на основі [9]

Як бачимо з табл. 2, найбільш привабливими за рівнем збитковості є страхування майна i агрострахування, однак саме ці види страхування i $\epsilon$ найбільш ризикованими, що можна побачити, якщо звернути увагу на темпи зміни показників збитковості по роках. Найбільш прогнозованими за рівнем збитковості є традиційні види страхування.

Висновки 3 проведеного дослідження. Серед головних видів страхування на ринку України найбільш привабливими за рівнем приросту страхових премій $є$ страхування відповідальності власників транспортних засобів та добровільне медичне страхування. Однак ці види страхування характеризуються також високим, але одночасно стабільним і прогнозованим рівнем збитковості. Найбільш ризикованими за коливанням рівня збитковості $\epsilon$ 
агрострахування і страхування майна. Найбільш стабільним за сукупністю досліджуваних критеріїв $є$ ринок страхування туристів.

\section{Перелік посилань}

1. Базилевич В.Д., Базилевич К.С., Пікус Р.В. Страхування: підручник. Київ: Знання, 2008. 648 с.

2. Базилевич В.Д., Пікус Р.В., Приказюк Н.В., Моташко Т.П. Страхові послуги: підручник у 2 ч. Ч. 2. К.: Логос, 2014. 527 с.

3. Cummins J.D., Doherty N.A. The economics of insurance intermediaries. Journal of Risk and Insurance. 2007. № 73. C. 347-349.

4. Любашенко I. Обов'язкове страхування цивільної відповідальності автовласників в Україні та Росії. Міфи та реальність. Страхова справа. 2004. №13. C. 46-51.

5. Ротова Т. Методичний інструментарій управління страховими ризиками. Фінанси України. 2002. №3. С. 122-128.

6. Фисун В. І., Ярова Г. М. Страхування. Навч. посіб. Київ: Центр учбової літератури, 2011. 232 с.

7. Прилипко С. М., Ярошенко О. М., Занфірова Т. А., Аркатов Я. А. Загальнообов'язкове державне соціальне медичне страхування в Україні: сучасний стан та стратегія розвитку: монографія. Харків, 2017. 208 с.

8. Білик О. І., Качмарчик С. А. Переваги та недоліки введення обов'язкової форми медичного страхування в Україні. Вісник Національного університету «Львівська політехніка». 2013. № 767. С. 270-277.

9. Рейтинг страховых компаний Украины. Фориншурер страхование : сайт. URL : https://forinsurer.com/ratings/nonlife (дата звернення : 28.11.2018).

10. Закон України "Про страхування" №2288-IV із змінами від 23.12.04. Відомості Верховної Ради. 2005. №6. С.138.

\section{References}

1. Bazylevych, V., Bazylevych, K., Pikus, R. (2008), Insurance: textbook [Strakhuvannia: pidruchnyk], Znannia, Kyiv, 648 p. 
2. Bazylevych, V., Pikus, R., Prykaziuk, N., Motashko, T. (2014), Insurance services: textbook [Strakhovi posluhy: pidruchnyk], Lohos, Kyiv, 527 p.

3. Cummins, J., Doherty, N. (2007), "The economics of insurance intermediaries". Journal of Risk and Insurance, No 73, P. 347-349.

4. Liubashenko, I. (2004), “Obligatory insurance of civil liability of car owners in Ukraine and Russia. Myths and reality" ["Oboviazkove strakhuvannia tsyvilnoi vidpovidalnosti avtovlasnykiv v Ukraini ta Rosii. Mify ta realnist"], Insurance business, No. 13, P. 46-51.

5. Rotova, T. (2002), "Methodological tools for insurance risk management" ["Metodychnyi instrumentarii upravlinnia strakhovymy ryzykamy"], Finance of Ukraine, No. 3, P. 122-128.

6. Fysun, V., Yarova, H. (2011), Insurance. Teaching manual [Strakhuvannia. Navch. posib.], Center of educational literature, Kyiv, 232 p.

7. Prylypko, S., Yaroshenko, O., Zanfirova, T., Arkatov, Ya. (2017), Obligatory State Social Health Insurance in Ukraine: Current State and Development Strategy: Monograph [Zahalnooboviazkove derzhavne sotsialne medychne strakhuvannia $v$ Ukraini: suchasnyi stan ta stratehiia rozvytku: monohrafiia], Kharkiv, 208 p.

8. Bilyk, O., Kachmarchyk, S. (2013), "Advantages and disadvantages of introducing compulsory medical insurance in Ukraine" ["Perevahy ta nedoliky vvedennia oboviazkovoi formy medychnoho strakhuvannia v Ukraini”], Bulletin of Lviv Polytechnic National University, No. 767, P. 270-277.

9. Rating of insurance companies of Ukraine. [Reitynh strakhovykh kompanyi Ukrayny. Forynshurer strakhovanye], available at : https://forinsurer.com/ratings/nonlife (last accessed 28.11.2018).

10. The Law of Ukraine "On insurance" №2288-IV as amended on 12/23/04. Information from the Verkhovna Rada, 2005, No. 6, P.138. 


\section{Онісіфорова В.Ю., Шершенюк О.М. СТАН ТА ПЕРСПЕКТИВИ РОЗВИТКУ СТРАХОВОГО РИНКУ УКРАЇНИ}

Mema. Визначення найбільш перспективних видів страхування для страхових компаній України за темпами росту показників страхових премій, страхових виплат та динаміки збитковості. Методика дослідження. При здійсненні дослідження використовувалися методи узагальнення, методи аналізу та синтезу, метод логічного аналізу. Інформаційною базою дослідження $\epsilon$ наукові праці, електронні інформаційні ресурси та матеріали періодичних видань. Результати. На сьогодні перед страховими компаніями постає проблема обрання перспективних напрямків розвитку з урахуванням таких головних критеріїв, як темпи зростання страхових премій на сегменті, темпи росту страхових виплат та динаміка збитковості за видами страхування. Портфель страхових продуктів за структурою останніми роками є доволі стабільним, без значних коливань та відхилень, однак у вартісному вираженні $\epsilon$ тенденція до збільшення розмірів отриманих страхових премій. Головними джерелами надходження коштів для страхових компаній України $є$ : страхування транспортних засобів від певних видів збитків; обов'язкове страхування цивільно-правової відповідальності власників наземних транспортних засобів; добровільне медичне страхування; страхування майна; страхування туристів; агрострахування. Ринок КАСКО має тенденцію до зростання, але темпи такого зростання зменшуються. Ринок обов'язкового страхування цивільно-правової відповідальності власників наземних транспортних засобів $є$ більш стабільним і має стабільні темпи до зростання. Перспективним є добровільне медичне страхування, яке має найбільші темпи зростання обсягів страхових премій. Нестабільним за рівнем страхових премій $\epsilon$ добровільне страхування майна, яке $\epsilon$ найменш збитковим, але при цьому темпи росту страхових премій 2018 року прогнозуються найменшими. Нестабільною $є$ і ситуація на ринку страхування туристів. Агрострахування $\epsilon$ найменш прогнозованим серед усіх видів страхування, бо рівень збитковості і рівень попиту на страхові послуги визначаються погодними умовами. Найбільш привабливими за рівнем збитковості $\epsilon$ страхування майна i агрострахування, однак вони $€$ найбільш ризикованими за динамікою показників збитковості. Найбільш прогнозованими за рівнем збитковості $\epsilon$ традиційні види страхування. Наукова новизна. Визначено перспективні види страхування 3 точки зору приросту обсягів страхових премій, динаміки страхових виплат та страхового ризику відповідно до рівня коливань збитковості. Практична значущість. Запропоновані висновки можуть бути використані науковцями та практиками при визначені перспектив розвитку страхового ринку України.

Ключові слова: страхування, страхові виплати, страхові премії, збитковість, динаміка.

\section{Онисифорова В.Ю., Шершенюк Е.Н. СОСТОЯНИЕ И ПЕРСПЕКТИВЫ РАЗВИТИЯ СТРАХОВОГО РЫНКА УКРАИНЫ}


Цель. Определение наиболее перспективных видов страхования для страховых компаний Украины по темпам роста показателей страховых премий, страховых выплат и динамики убыточности. Методика исследования. При осуществлении исследования использовались методы обобщения, методы анализа и синтеза, метод логического анализа. Информационной базой исследования являются научные труды, электронные информационные ресурсы и материалы периодических изданий. Результаmы. Сегодня перед страховыми компаниями встает проблема выбора перспективных направлений развития с учетом таких основных критериев, как темпы роста страховых премий на сегменте, темпы роста страховых выплат и динамика убыточности по видам страхования. Портфель страховых продуктов по структуре последние годы довольно стабилен, без значительных колебаний и отклонений, однако в стоимостном выражении наблюдается тенденция к увеличению размеров полученных страховых премий. Главными источниками поступления средств для страховых компаний Украины являются: страхование транспортных средств от определенных видов убытков; обязательное страхование гражданско-правовой ответственности владельцев наземных транспортных средств; добровольное медицинское страхование; страхование имущества; страхование туристов; агрострахование. Рынок КАСКО имеет тенденцию к росту, но темпы этого роста уменьшаются. Рынок обязательного страхования гражданско-правовой ответственности владельцев наземных транспортных средств является более стабильным и имеет стабильные темпы роста. Перспективным является добровольное медицинское страхование, которое имеет наибольшие темпы роста объемов страховых премий. Нестабильным по уровню страховых премий является добровольное страхование имущества, являющегося наименее убыточным, но при этом темпы роста страховых премий 2018 прогнозируются наименьшими. Нестабильна и ситуация на рынке страхования туристов. Агрострахование является наименее прогнозируемым среди всех видов страхования, так как уровень убыточности и уровень спроса на страховые услуги определяются погодными условиями. Наиболее привлекательными по уровню убыточности является страхование имущества и агрострахование, однако они являются наиболее рискованными по динамике показателей убыточности. Наиболее прогнозируемыми по уровню убыточности являются традиционные виды страхования. Научная новизна. Определены перспективные виды страхования с точки зрения прироста объемов страховых премий, динамики страховых выплат и страхового риска в соответствии с уровнем колебаний убыточности. Практическая значимость. Предложенные выводы могут быть использованы учеными и практиками при определении перспектив развития страхового рынка Украины.

Ключевые слова: страхование, страховые выплаты, страховые премии, убыточность, динамика.

Onisiforova V.Yu., Shershenyuk O.M. THE STATE AND THE PROSPECTS OF UKRAINE INSURANCE MARKET 
Purpose. The determination of the most promising types of insurance for Ukrainian insurance companies at rates of growth of insurance premiums, insurance payments and losses dynamics.. Methodology of research. The methods of compilation, of analysis and synthesis and of logical analysis were used at the research. The scientific works, electronic resources and periodical publications were information base of the research. Findings.

Now the insurance companies has a problem of the election promising areas with the following main criteria as the rate of growth of premiums in the segment, growth dynamics of insurance benefits and losses by types of insurance. The portfolio of insurance products by structure in recent years is rather stable, without significant fluctuations and variations, but in value terms there is a tendency to increase the size of received insurance premiums. The main sources of funds for insurance companies in Ukraine are: insurance of vehicles from certain types of losses; obligatory insurance of civil liability of owners of land vehicles; voluntary medical insurance; insurance of property; insurance of tourists; agricultural insurance. The CASCO market has a tendency for growth, but the pace of this growth is decreasing. The market for compulsory civil liability insurance for land vehicle owners is more stable and has a steady growth rate. Promising is voluntary medical insurance, which has the highest growth rates of insurance premiums. Voluntary insurance of the property, which is the least unprofitable, is volatile by the level of insurance premiums, but at the same time the growth rates of insurance premiums in 2018 are forecasted to be the lowest. The situation on the tourist insurance market is also unstable. Agricultural insurance is the least predictable of all types of insurance, since the level of unprofitability and the level of demand for insurance services are determined by weather conditions. The most attractive in terms of property loss is insurance and agricultural insurance, but they are the most risky for dynamic performance loss. Most predicted by the level of losses is traditional insurance. Originality. The perspective types of insurance are determined from the point of view of increase in the volume of insurance premiums, dynamics of insurance payments and insurance risk in accordance with the level of fluctuation of losses. Practical value. The proposed conclusions can be used by scientists and practitioners in determining the prospects for the development of the insurance market in Ukraine.

Key words: insurance, insurance payments, insurance premiums, losses, dynamics.

Онісіфорова Валентина Юріївна - кандидат економічних наук, доцент, Харківський національний автомобільно-дорожній університет, доцент кафедри економіки i підприємництва, м. Харків, Україна; e-mail: valentinaonisiforova@gmail.com; ORCID ID: https://orcid.org/0000-0001-98998427. Моб. 099-499-14-28.

Онисифорова Валентина Юрьевна - кандидат экономических наук, доцент, Харьковский национальный автомобильно-дорожный университет, доцент кафедры экономики и предпринимательства, г. Харьков, Украина. 
Onisiforova Valentyna - Candidate of Sciences (Economics), Associate Professor, Kharkov National Automobile and Highway University, Associate Professor at the Department of Economics and Entrepreneurship, Kharkiv, Ukraine.

Шершенюк Олена Миколаївна - кандидат економічних наук, доцент, Харківський національний автомобільно-дорожній університет, доцент кафедри економіки і підприємництва, м. Харків, Україна; е-mail: sheralyona @ gmail.com; ORCIDID: https://orcid.org/0000-0002-9959-2725. Моб. 0501513009

Шершенюк Елена Николаевна - кандидат экономических наук, доцент, Харьковский национальный автомобильно-дорожный университет, доцент кафедры экономики и предпринимательства, г.Харьков, Украина

Shershenyuk Elena Nikolaevna - Candidate of Science (Economics), Associate Professor, Kharkiv National Automobile and Highway University, Associate Professor, Department of Economics and Entrepreneurship, Kharkiv, Ukraine 